\title{
Mathematical Relations for Harmonization with Technical and Decorative Casting Nature
}

\section{Matemātiskās sakarības tehniskās un dekoratīvās kalšanas darbu harmonizēšanai}

\author{
Volodymyr Doroshenko ${ }^{1}$, Olena $\mathrm{Mul}^{2}$, Olena Kravchenko ${ }^{3}$ \\ ${ }^{1}$ Physico-Technological Institute of Metals and Alloys, Ukraine \\ ${ }^{2}$ Ternopil National Ivan Puluj Technical University, Ukraine \\ ${ }^{3}$ International Research and Training Centre for Information Technologies and Systems, Ukraine
}

\begin{abstract}
We have considered optimization of casting design in the concept of its interaction with two fluid technological mediums, namely, the interaction of its pattern with a sandy medium and the mould - with metal. A metal saving method is proposed and an overview of publications on technical castings design according to this method is presented. The examples of decorative castings are shown, in the design of which the laws of the golden ratio and Fibonacci numbers are reflected, as well as castings produced at the Physico-Technological Institute of Metals and Alloys (Kyiv, Ukraine).
\end{abstract}

Keywords - Casting design, metal saving, lightweight casting, lost foam casting, decorative articles, the golden ratio, Fibonacci numbers.

\section{INTRODUCTION}

One of actual trends in mechanical engineering and foundry production is the science of technologization in order to reduce the weight of metal structures, first of all vehicles, and to increase their operating life. Modern cast metal products in Europe due to the used casting processes and traditional conditions of their design exceed the calculated service indicators by 1.3 to 2 times [1]. This leads to overspending of energy carriers and charge materials as well as labour intensity of the foundry production. Costs of energy, fuel and lubricants of operating machines and mechanisms created on the basis of cast parts of high metal consumption are at least $20 \%$ to $30 \%$ higher than in the case of using optimal cast parts.

Thus, new approaches for assessing the operational characteristics of metal products and predicting the properties of casting materials and technologies are needed to implement metal saving. Therefore, computer information technologies and adapted computer programs, which reflect the conditions of filling the mould, feeding prone to shrinkage units, crystallization and structure formation of castings, are used.

In the process of improving the automated design systems of cast constructions it is necessary to involve the new achievements in the technology of casting alloys and moulding processes in their optimum combination [1] and to include the latest developments in the field of exact methods of producing castings.

Lost Foam Casting (LFC) has great prospects.

\section{ANALYSIS OF LATEST INVESTIGATIONS}

Based on some mathematical methods, analysis, identification and a series of experiments on optimization of cast technical lightweight metal constructions were carried out under the scientific supervision of O. Shinskiy [2], [3].

Method of copying in metal nature structures, selected by evolution, as innumerable examples of perfection and resource saving, has a great potential [4], [5], in particular, using the LFC process.

Here, it is suggested to consider the casting and forming as a concept of joint effect on it of such two fluids as pouring metal, replacing the casting pattern from the inside, and movable sand medium, flowing around the pattern surface from the outside, taking into account the optimal filling of the mould by sand.

With the help of mathematical and computer modelling it became possible to develop lightweight cellular resource saving constructions of cast metal products by analogues of microstructures of solid substance, some biological structures and nanomaterials with their physical modelling from serial parts, made from gas-filled hydrocarbon polymers [2]-[5].

In these works, which contain more than a dozen patented designs of technical castings or patterns for their production, the well-known fact of the prevalence of spiral elements in nature structures, in particular with characteristics relating to the "golden section" concept, was noted.

Let us consider in detail the regularities related to this concept known from ancient times. It is generally accepted that it was applied in scientific research by Pythagoras in the 6th century BC. In ancient literature the description of segment division in extreme and mean ratio, i.e. the golden section, was first mentioned in the work of Euclid and it was approximately equal to 1.618 [6], [7]. Once the form of a spirally curled shell attracted the attention of Archimedes, who derived the spiral equation. The spiral, drawn according to this equation, was named after him, and the increase in its step is always uniform. 
Besides, for the Fibonacci sequence, except for its initial numbers, the special number $1.618 \ldots$ is approximately equal to the ratio of any subsequent number to the preceding one, whereas the special number $0.618 \ldots$ is approximately equal to the ratio of any preceding number of the subsequent one.

The numbers of the Fibonacci sequence appear everywhere in nature: in a spiral, along which plant branches adjoin to a stem, as well as in a spiral, along which scales on a cone or grains on a sunflower grow. Scientists found this spiral form with features of the Fibonacci sequence in a variety of things, such as hurricanes, spiral seeds, cochlea of the human ear, ram's horn, seahorse tail, growing fern leaves, the DNA molecule, waves hitting the shore, tornadoes, galaxies, the tail of a comet orbiting the Sun, a whirlpool, spider's web.

Also, examples of the golden section ratio can be found in the human body, as it can be seen in Fig. 1 presenting the illustrations from open Internet sources.

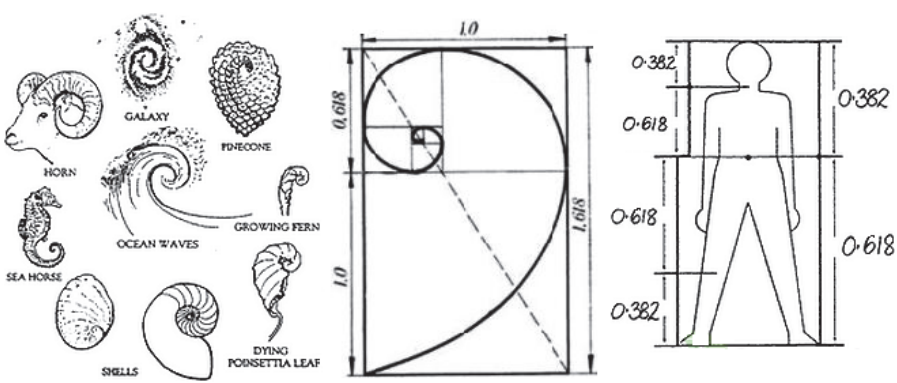

Fig. 1. Examples of the presence of Archimedes spiral and Fibonacci numbers in nature.

One of the modern examples of the golden ratio application is the use of the Penrose tiling [5]. The proportion of the golden section is perceived by the human eye as beautiful and harmonious.

The observed in nature principle of the golden ratio, which reflects the structural and functional perfection of the whole and its parts, is used in art, science and engineering. Art gives a huge number of examples of application of the golden section: the pyramid of Cheops, the Pantheon and the Parthenon in Athens, the majority of Greek sculptures, including Doryphoros and the Venus de Milo, "Mona Lisa" by Leonardo da Vinci, paintings by Raphael and Michelangelo, buildings by architects Bazhenov and Malevich, and many others [9].

Also, there exist so called "golden" figures: rectangle, triangle, pentagon, built on the basis of the specified ratios of sides. In Fig. 2 we can see that the first two figures from left which are in the structure of jewelry castings, were produced with the help of the 3D-printer taking into account the Fibonacci ratios.

Ratios for geometric structures in art are characterized by the concept of plasticity, which means a harmonious ratio of forms and lines.

Both natural and artificial world is built according to the same universal laws, and a person consciously or intuitively uses these universals [10].
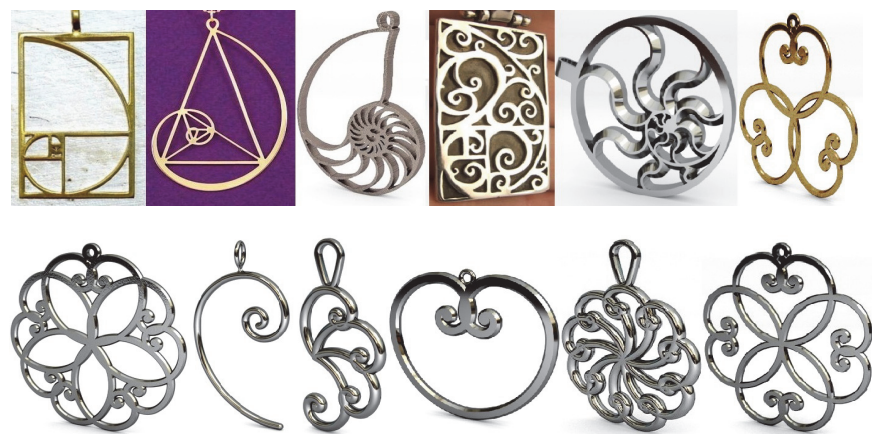

Fig. 2. Examples of jewelry castings with elements of e "golden" figures and spirals.

The proportions of decorative castings (Fig. 3)-(Fig. 5), used in landscape gardening compositions or in the design of premises and buildings, also correspond to these "laws of beauty."

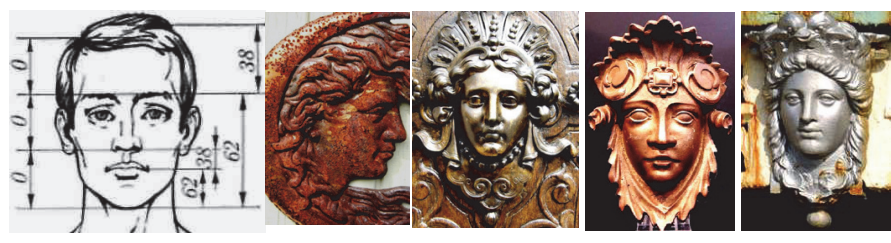

Fig. 3. Examples of correspondence of facial features to the Fibonacci sequence in images of face in decorative castings.

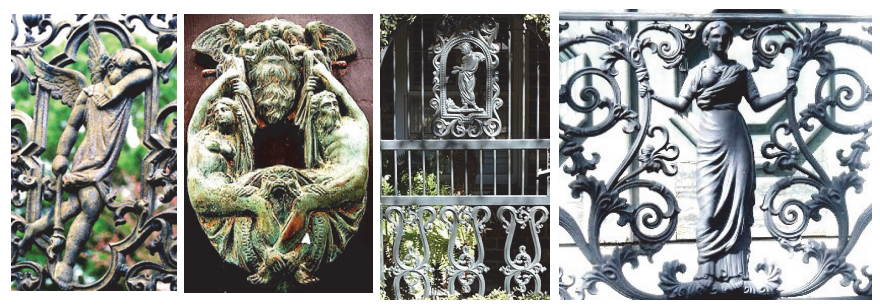

Fig. 4. Examples of decorative castings with images of human figures.
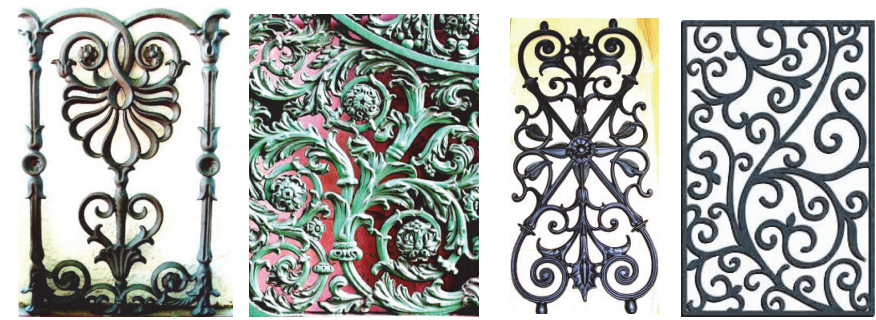

Fig. 5. Cast products from spiral elements.

The maximum accordance with the golden section, in the opinion of many scientists, artists and sculptors, is the ideal beauty to the human eye.

In the above mentioned examples, the photographs of decorative castings, constructions of which contain images of human faces or figures, are taken mainly from touristic and architectural descriptions as well as from exhibition reports (Fig. 2)-(Fig. 7).

\section{REVIEW OF CASTING DESIGNS AND Discussion}

Introduction of human figure in decorative cast fences, ritual and other compositions changes the ratios of forms of their geometrical structure. This type of ratio occurs when 
comparing rectilinear and curvilinear forms, i.e. the natural and artificial ones.

In some photos (Fig. 3), (Fig. 4) we can see the spiral elements, which are analogous to those shown in Fig. 1 and Fig. 2. The examples of thin-walled cast ornaments, consisting of such elements, are shown in Fig. 5.

Figure 6 shows the ratios of hand sizes, corresponding to the Fibonacci numbers, as well as the cast sculptures of hands, made from ferrous and non-ferrous metals.
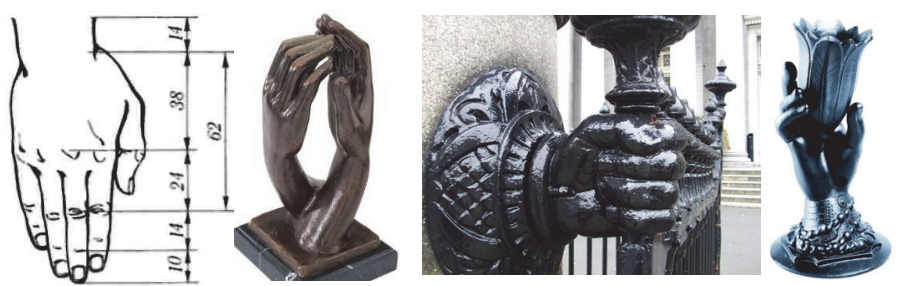

Fig. 6. Examples of hand sizes corresponding to the Fibonacci ratios and images of hands in decorative castings.

In Fig. 6 the second image from left shows the cast sculpture of Rodin, the third image presents a large metal gate hinge in the form of a hand, and the fourth image shows a cast iron pencil holder in the form of a hand with tulip, produced by Kasli.

Scientists think that Fibonacci numbers dominate in plant spirals because plants are programmed to follow a certain set of laws of development and such "patterns" give them evolutionary advantage.

As an example, let us consider the growth of chicory. Each next sprout from the main stem produces a leaf shorter than the previous one, makes a sprout again, but already shorter one, then again produces a leaf even shorter, and again a shorter sprout, etc. If the first sprout is taken for 100 units, then the second one is equal to 62 units, the third one - to 38 , the fourth one - to 24 , etc. The length of the petals is subordinated to the golden ratio. In the growth and the conquest of space, the plant retains these proportions, and impulses of its growth gradually decrease in the proportion of the golden section.

The growth of plants in nature is a perfect example of the general appropriateness of Fibonacci ratio. Fibonacci numbers can be found in the amount of branching on a stem of each growing plant as well as in the number of petals. Plant motifs in cast metal are shown in Fig. 7.

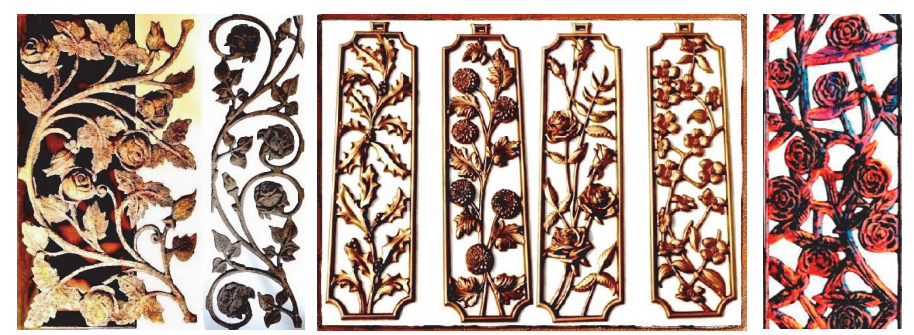

Fig. 7. Stylized plants in the cast metal.

Sculptors and casters, following the laws of harmony, create decorative castings, which the viewer consciously or unconsciously perceives as internal structural laws of organization of the art form, implemented in the product by means of skill and creativity. Adherence to such internal laws of creating the art form, in particular, to the described spiral constructions and Fibonacci sequences, does not prevent artists to create new, no less vivid, figuratively unrepeatable products analogously to nature, creating uncountable examples of perfection in accordance with its laws.

Many casters, thanks to their skill and talent, intuitively felt the above described laws of artistic forming and passed on the obtained artistic experience. In this way they created the traditions of technical schools of decorative and art casting, turning this experience into technology standards. Thus, in the process of casting, which often borders with art, following the principles of search for perfection of the cast product form, the fundamental principle of harmony "unity in diversity" is realized.

The Scientific-Technical School of foundry production at the Physico-Technological Institute of Metals and Alloys (Kyiv, Ukraine) has accumulated significant experience in casting thin-walled technical and decorative metal products. The Institute is a leading developer and patent holder of a number of variations of LFC process and it has the scientific and industrial knowledge, accumulated since the $60 \mathrm{~s}$ of the last century, on introducing this process into production. In workshops and laboratories of the Institute castings are constantly produced and their production technologies are improved.

Presently, for automation of production of patterns from foamed polystyrene, $\mathrm{CNC}$ machines and 3D-mills are used [11], [12]. This allows producing one-time patterns of castings of small series or the pattern of the mould equipment for obtaining castings of greater seriality with minimal costs. Cast aluminium moulds are processed on the same machines. With the help of such patterns it is possible to obtain the castings, samples of which are shown above.

When producing patterns with the help of CNC machines for cutting styrofoam, the three-dimensional pattern of the complex part is divided into simple elements, which are cut on the machine. Then, they are glued together and large size patterns with a rather complex form are obtained, for example, corps of large engines, pumps, reducers, decorative thinwalled castings, etc. Such production of patterns for casting in small-serial and individual cases according to the LFC process reduces time and labour costs whereas the production of mould in another way is uneconomical. According to this technology, the molten metal is poured directly onto the body of the gate of the foam pattern and changes it into the mouldable mixture. The analysis of the LFC process economy is described in [13] and compared with other casting processes.

Based on [11] let us summarize the stages of pattern production at the 3D-mill, which are as follows: The volume model of the detail is constructed in the three-dimensional CAD-system, for example, in the SolidWorks, Kompas 3D, CATIA, Autodesk Inventor, etc. The volume model is divided into simpler fragments, which can be technologically cut on the machine of foam plastic figural cutting. The contours of the fragments are assembled in the foam preform size and the 
files of control programs are prepared. Cutting is produced at the 3D-mill (Fig. 8) and, if necessary, the manual finishing of details is carried out. After that, the assembly of fragments into the pattern is performed.
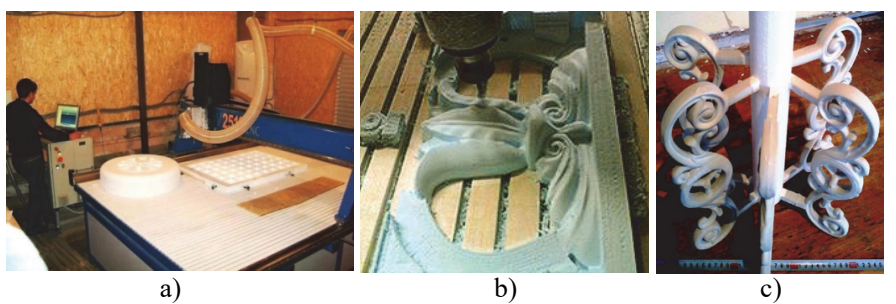

Fig. 8. a) The process of polystyrene foam pattern production at the $3 \mathrm{D}$-mill; b) the work of the mill during the cutting of decorative pattern; c) the cluster in the assembly of four decorative patterns with spiral elements.

In Fig. 9 the examples of the production of polystyrene foam patterns and castings of decorative products are shown, made under the leadership of the chief technologist V. Melnyk (Fig. 9)-(Fig. 14), where the stages of the technological process from pattern to casting can be seen.
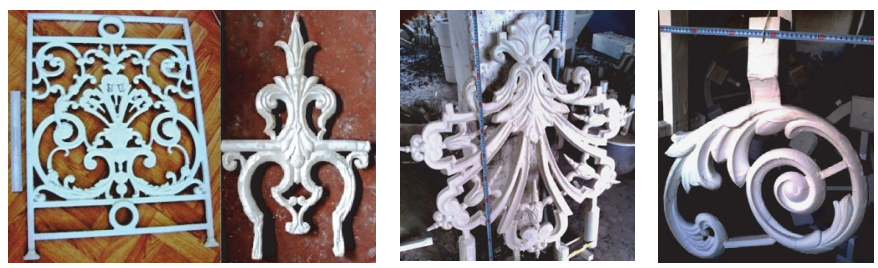

Fig. 9. The large patterns of castings decorative lattices of fences.
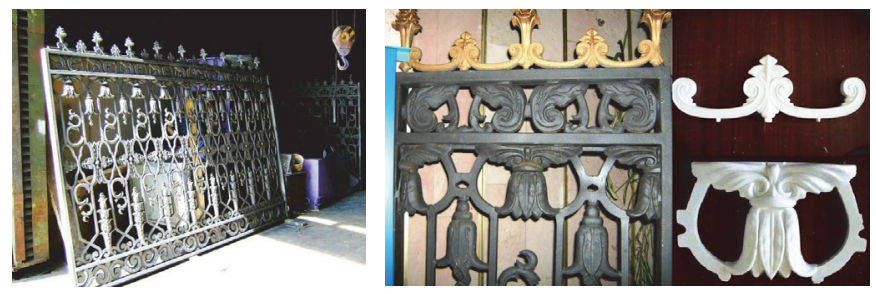

Fig. 10. A large cast-welded section of a decorative fence from carbon steel in the shop of the Physico-Technological Institute of Metals and Alloys (Kyiv, Ukraine) as well as its fragment with patterns of its constituent parts.

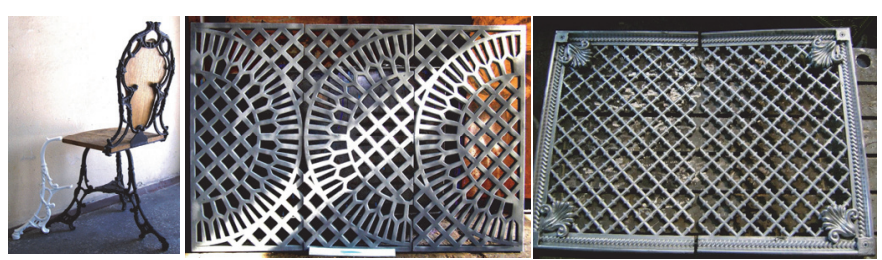

Fig. 11. A chair with cast iron framework, three sectional cast-iron lattice and two sectional brass lattice.

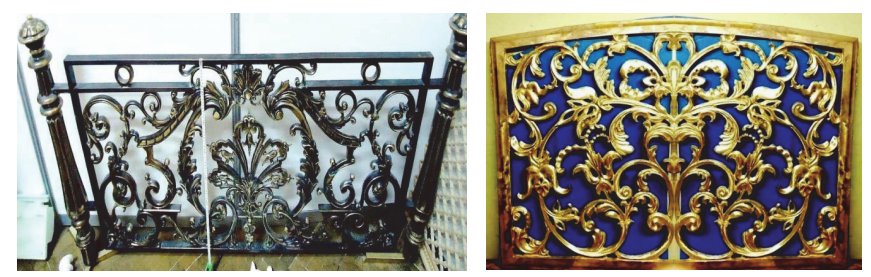

Fig. 12. Two brass lattices.
In Fig. $14 \mathrm{c}$ ) shows the cavity, cut out in the polystyrene foam block by the 3D-mill and intended for further production of mold pattern, polystyrene foam pattern and cast iron casting of the decorative fence detail. This practically shows the cycle of the production of equipment elements and the metal casting.
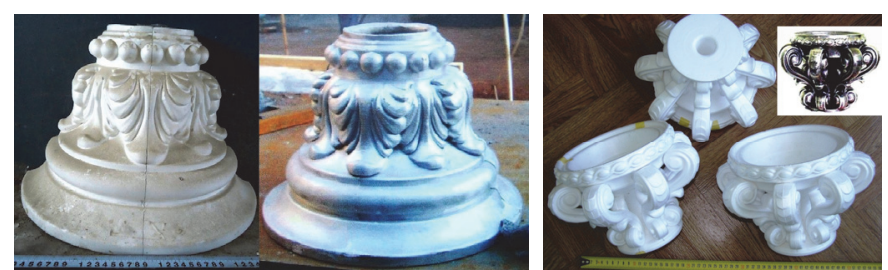

Fig. 13. The pattern and the hollow aluminium casting of the stand under the column, as well as 3 patterns and the casting of the stand under the street lamp plafond.

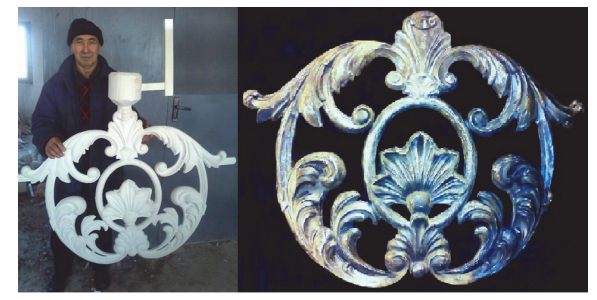

a) b)

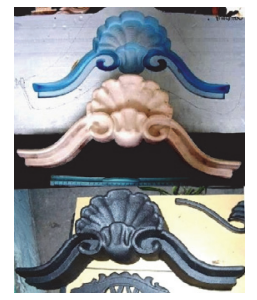

c)
Fig. 14. The pattern and the casting of the fence detail from stainless steel, as well as the pre-form of the mould pattern, the pattern and the casting of the decorative fence detail.

\section{CONCLUSION}

The authors of the paper considered the optimization of casting design in the concept of its interaction with two fluid technological mediums, namely, interaction of its pattern with sandy medium and the mould - with a metal. The method of harmonization of metal products by means of copying the structures, observed in nature is proposed. The considered mathematical laws of such structures can ensure metal saving with the optimal ratio of indicators of service properties of the extended material.

Recently, articles on art casting technologies are very rare in the technical periodical press. Therefore, in the review the emphasis is placed on the demonstration of practical examples of the production of decorative castings, where founders consciously or intuitively reflect the laws of the golden ratio and Fibonacci numbers. Such approach to the construction of metal products allows increasing the attractiveness of their look, and the harmonization of shapes and sizes contributes to metal saving during their production.

Besides that, the popularization of high-tech casting processes and computerization of patterns production at the 3D-mill can effectively and quickly attract the attention when reviewing the examples of remarkable decorative and art products as samples, which better demonstrate the capabilities of the considered modern production processes. 


\section{REFERENCES}

[1] O. I. Shinskiy, "Reduction of Metal Consumption of Casting Products the Basis of the Branch Development," Equipment and Tools for Professionals, no. 1, pp. 78-79, 2011. (in Russian)

[2] V. S. Doroshenko, "Proposals for Metal Saving When Casting HighDuty Cast Iron in Sand Molds," Metal and Casting of Ukraine, no. 2, pp. 28-35, 2016. (in Russian)

[3] V. S. Doroshenko, Metal Casting in Vacuum Sand Molds on Continuous Action Conveyor Lines, Saarbruücken: Lambert Academic Publishing, 2015, $112 \mathrm{p}$.

[4] V. S. Doroshenko, "Analysis and Identification of Cast Lightweight Metal Structures Using the Theory of Minimal Surfaces," Metal and Casting of Ukraine, no. 11, pp. 24-28, 2015. (in Russian)

[5] V. Doroshenko, O. Mul, and O. Kravchenko, "Prospects for ComputerAided Design of Casting" Boundary Field Problems and Computer Simulation, vol. 53, pp. 4-8, 2014 https://doi.org/10.7250/bfpcs.2014.001

[6] V. S. Doroshenko, "Methods of Obtaining Frame and Cellular Cast Materials and Details by Gasified Patterns," Liteinoye Proizvodstvo, no. 9, pp. 28-32, 2008. (in Russian)

[7] V. S. Doroshenko, Design of Lightweight Cast Frame and Cellular Metal Constructions with the Help of Modeling Nature Structures, Saarbruücken: Lambert Academic Publishing, 2015, 54 p.

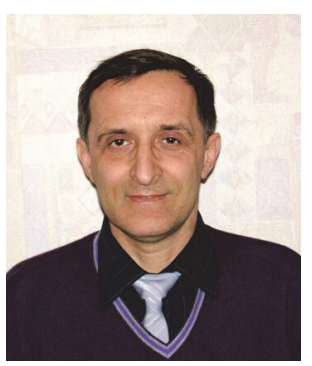

Doroshenko Volodymyr received the Ph.D. degree in Technical Sciences in 1990 from Kyiv Polytechnical Institute, Kyiv, Ukraine. The theme of the thesis was "Obtaining of Castings of Hydrodistributors from Cast Iron with Globular Graphite in Vacuum-Processed Moulds". He is currently a Senior Research Fellow with Physico-Technological Institute of Metals and Alloys, Ukraine.

His major areas of scientific activity are heat and mass transfer, gas and hydrodynamics of the interaction of a melt and a crystallizing metal with sand casting mould, physics and chemistry of processes of sand casting mould production, particularly with the use of vacumization; new methods of forming for foundry, which ensure an environmental safety of production and improve the quality of metal castings; methods of casting into vacuumprocessed moulds; use of cryo-technologies in foundry, in particular, technological bases of accurate blanks obtaining by single-use ice models. He is the author of more than 340 scientific and technical papers, including about 80 patents for inventions of Ukraine and Russia.

E-mail: doro55v@gmail.com

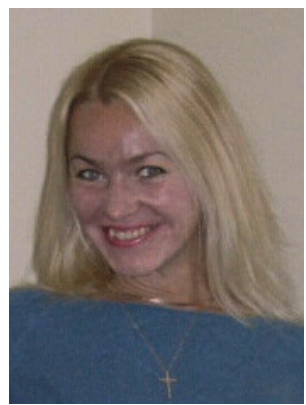

Mul Olena received the Ph.D. degree in Physics and Mathematics in 2001 from the Space Research Institute of NASU-NSAU, Kyiv, Ukraine. The theme of her thesis was "Analysis of Self-Oscillation Processes in the Complex Continuous and Discrete Systems". She is currently an Associate Professor with the Computer-Integrated Department of Ternopil National Ivan Puluj Technical University, Ukraine.

Her major areas of scientific activity are control theory on time scales with special emphasis on hybrid systems; controllability and optimality of nonlinear control systems; analysis and control of dynamical systems; numerical analysis; perturbation theory; theory of vibrations; mathematical
[8] A. P. Stakhov, "Mathematics of Harmony. From Euclid to Modern Mathematics and Computer Science", Measuring and Computing Devices in Technological Processes, no. 1, pp. 7-15, 2013. (in Russian)

[9] O. Ya. Bodnar, The Golden Section and Non-Euclidean Geometry in Science and Art, Lviv: Ukrainian Technologies, 2005, 198 p. (in Ukrainian)

[10] S. P. Doroshenko, O. N. Magnitsky, V. Yu. Mogilevskiy, and V. Yu. Pirainen, The History of Art Casting, St. Petersburg: Publishing House of St. Petersburg State Polytechnic University, 2006, 312 p. (in Russian)

[11] I. O. Shinskiy and V. S. Doroshenko, "3D Technologies in Lost Foam Casting," Metal and Casting of Ukraine, no. 4-5, pp. 30-33, 2009. (in Russian)

[12] V. Doroshenko, O. Mul, and O. Kravchenko, "Modeling of the Process of Three-Dimensional Metal Casting," Boundary Field Problems and Computer Simulation, vol. 54, pp. 5-9, 2015. https://doi.org/10.7250/bfpcs.2015.002

[13] V. S. Doroshenko and V. O. Shinskiy, "Examples of Calculations of Technical and Economical Parameters of Casting Processes for OneTime Patterns," Casting Processes, 2015, no. 6, pp. 35-47, 2015. (in Russian)

physics and computational mathematics for nonlinear boundary value problems in PDE's and ODE's. She is a member of IAMP. She has received grants from INTAS, IUPAP, NATO, ESF, UNESCO, CIME, C.I.R.M., the Banach Centre (Warsaw, Poland), Max Planck Institute of Physics of Complex Systems (Dresden, Germany). She has received a FCT post-doctoral fellowship "Analysis of Vibrations in Nonlinear Dynamical Systems" with the Department of Mathematics, University of Aveiro, Portugal (2004-2007); 6 months scientific fellowship "Numerical and Asymptotical Methods for Highly Oscillatory Differential Equations" with the Department of Applied Mathematics and Theoretical Physics, Centre for Mathematical Sciences, University of Cambridge, UK (2012).

E-mail: ms.olena@gmail.com

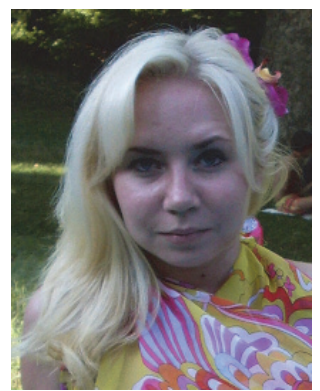

Kravchenko Olena has been a post-graduate student with International Research and Training Centre for Information Technologies and Systems of NASU-MESU, Kyiv, Ukraine, since 2012. Currently she is a Software Engineer with Glushkov Institute of Cybernetics of NASU, Kyiv, Ukraine.

Her major areas of scientific activity are the group method of data handling (GMDH) and other methods of inductive modelling under assumptions; robotics problems on using a mobile robot manipulator for repair and rescue works under extreme conditions of catastrophic situations in underground mining constructions; ecological problems on development of geo-information systems for the prediction of natural meteorological disasters; the interval method of telemetry information reliability control for monitoring the casting cooling in a sand mould; mathematical methods for assessing the quality of cast iron by temporal experimental data; monitoring and geo-processing of the earth surface probing processes. She is the author of more than 20 publications, published in scientific journals and presented at International and Ukrainian scientific conferences.

E-mail: len327@ukr.net 
Matemātiskās sakarības tehniskās un dekoratīvās kalšanas darbu harmonizēšanai

Volodymyr Dorošenko ${ }^{1}$, Oḷena Mul $^{2}$, Oḷena Kravčenko ${ }^{3}$

${ }^{1}$ Metālu un to sakausējumu fizikāli tehnologiskais institūts, Ukraina

${ }^{2}$ Ivana Puluja Ternopiles Nacionālä Tehniskä universitāte, Ukraina

${ }^{3}$ IT un sistēmu Starptautiskais pētniecības un apmācību centrs, Ukraina

Viens no aktuālajiem virzieniem inženiermehānikā un lietuvju darbībā ir zinātnes lietošana, lai samazinātu metāla struktūru svaru un palielinātu produkcijas lietošanas laiku bez papildu enerğijas, izejmateriālu un darbaspēka lietošanas. Šo iemeslu dēḷ tiek lietotas datortehnolog̣ijas un pielāgotas datorprogrammas, kuras modelē veidnes piepildīšanas un kristalizācijas apstākḷus, kā arī lējuma struktūras formēšanu.

Kā metāla ietaupīšanas paṇēmiens šajā rakstā tiek piedāvāta metode, saskaṇā ar kuru metāla produktos tiek atdarinātas dabīgas struktūras, kuras dabā ir radušās evolūcijas rezultātā. Šai metodei ir liels potenciāls, it īpaši, lietojot LFC (Lost Foam Casting) procesu. Tiek uzskatīts, ka lējuma konstrukcijas optimizācija ir saistīta ar mijiedarbību starp diviem škidrumiem, piemēram, izkausētu metālu, kas aizpilda lējuma šablonu no iekšpuses, un pārvietojamu smilšu vidi, kas plūst ap šablona ārpusi. Rakstā uzsvars tiek likts uz dekoratīvu lējumu piemēriem, kur konstrukcijā tiek ņemts vērā zelta šķēlums un Fibonači skaitļi. Rakstā ir parādīti piemēri dekoratīvu produktu lējumu veidošanai, kas tiek veikti PTIMA (Physico-Technological Institute of Metals and Alloys (Kyiv, Ukraine)), kur tehnoloğiskā procesa soḷi no šablona līdz lējumam ir redzami. Lietotie matemātiskie likumi noved pie metāla ietaupījuma un optimālās ražošanas izmaksu un izlietoto materiālu attiecības. Turklāt šāda pieeja metāla produktu ražošanā dod iespēju uzlabot šo produktu izskatu.

Atslēgas vārdi - Dekoratīvie produkti, Fibonači skaitḷi, lējumu ražošana, metālapstrāde, zelta šḳ̄ēlums. 